\title{
Cutaneous Mastocytosis in Children: Is It Just a Skin Disease?
}

\section{Çocuklarda Kutanöz Mastositoz: Sadece Bir Deri Hastalığı mı?}

\author{
Tuğba Aktürk ${ }^{1}\left(\mathbb{D}\right.$, Emine Türkkan² $^{(\mathbb{D}}$, Deniz Özçeker ${ }^{3}$ (D) \\ ${ }^{1}$ Hakkari State Hospital, Department of Pediatrics, Istanbul, Turkey \\ ${ }^{2}$ University of Health Sciences, Prof. Dr. Cemil Taşcıoglu City Hospital, Department of Pediatric Hematology, Istanbul, Turkey \\ ${ }^{3}$ University of Health Sciences, Prof. Dr. Cemil Taşcıoglu City Hospital, Department of Pediatric Allergy and Immunolgy, Istanbul, Turkey
}

ORCID ID: T.A. 0000-0002-7136-3023; E.T. 0000-0002-5126-7843; D.Ö. 0000-0002-0032-6727

Citation/Atf: Akturk T, Turkkan E, Ozceker D. Cutaneous mastocytosis in children: is it just a skin disease? Çocuk Dergisi - Journal of Child 2021;21(2):198-202. https://doi.org/10.26650/jchild.2021.896136

\section{ABSTRACT}

Introduction: Mastocytosis is characterized by the excessive proliferation and accumulation of mast cells in organs such as the spleen, liver, lymph nodes, skin, gastrointestinal tract, and bone marrow. Cutaneous mastocytosis, which is only presented with skin involvement, is frequently seen in childhood.

Objective: It was aimed to determine the demographic and clinical characteristics of patients with cutaneous mastocytosis and the knowledge level of families about the disease, and to raise awareness about this disease.

Material and Methods: The records of 25 cases with cutaneous mastocytosis were evaluated retrospectively and the knowledge levels of the families were measured with a questionnaire.

Results: The mean follow-up period of 25 patients was 39 months. The most common type of the disease was urticaria pigmentosa (60\%). Itching $(n=14)$ was the most common symptom in patients. Only 2 patients were carrying adrenaline auto-injectors. While $60 \%$ of the families $(n=15)$ had fears about the disease; of these 15 families, $53.3 \%(n=8)$ were afraid of the re-spread of the disease, $13.3 \%(n=2)$ turning of the disease into skin cancer, $13.3 \%(n=2)$ occupation of the internal organs, $13.3 \%(n=2)$ having a new attack, and $0.4 \%(n=1)$ re-forming of the spots.

Conclusion: The cutaneous forms of mastocytosis are mostly observed in childhood, and systemic involvement is rare. Mastocytosis progresses with rashes in childhood and its findings are limited to the skin. Families should be better informed about mastocytosis and the need for patients to carry an adrenaline auto-injector due to the risk of attacks should be explained to them.

Keywords: Anaphylaxis, cutaneous mastocytosis, mastocytosis
ÖZ

Giriş: Mastositoz, mast hücrelerinin dalak, karaciğer, lenf nodu, deri, gastrointestinal yol, kemik iliği gibi organlarda aşırı çoğalması ve birikmesi ile karakterize bir hastalıktır. Sıklıkla çocukluk çağında sadece deri tutulumu ile seyreden kutanöz mastositoz tipi görülür.

Amaç: Kutanöz mastositozlu hastaların demografik ve klinik özelliklerini belirlemek, ailelerin hastalık hakkında bilgi düzeylerini ölçmek ve bu hastalık hakkında farkındalık oluşturmak amaçlanmıştır.

Gereç ve Yöntemler: Kutanöz mastositoz tanısı alan 25 olgunun dosyası geriye dönük olarak değerlendirildi ve ailelere kutanöz mastositoz ile ilgili bilgi düzeylerini ölçmek için anket uygulandı.

Bulgular: İzlem süresi ortalama 39 ay olan 25 kutanöz mastositozlu hasta çalışmaya dahil edildi. Hastaların \%60'ı ürtikerya pigmenzota tipinde idi. Kaşıntı en sık olarak görülen semptom ( $n=14)$ idi. Sadece 2 hastamız adrenalin oto enjektörü taşımaktaydı. Ailelerin $\% 60$ 'ında $(n=15)$ hastalık ile ilgili korkular mevcuttu; bu 15 ailenin $\% 53,3^{\prime}$ ü $(n=8)$ hastalığın tekrar yayılmasından, \%13,3'ü (n=2) cilt kanserine dönüşmesinden, \%13,3'ü $(n=2)$ iç organların tutulmasından, \%13,3'ü $(n=2)$ atak geçirmesinden, $\% 0,4$ 'ü $(n=1)$ lekelerin tekrar oluşmasından korkmakta idi

Sonuç: Mastositoz çocukluk çağında döküntülerle beraber seyreden ve kendini cilt bulguları ile sınırlayan bir hastalıktır. Çocukluk çağında daha çok kutanöz formu görülen hastalığın sistemik tutulumu nadir görülür. Ailelerin mastositoz hastalığı hakkında bilgilendirilmesi ve atak geçirme riskine yönelik adrenalin oto enjektörü taşıması gerekliliği anlatılmalıdır.

Anahtar Kelimeler: Anafilaksi, kutanöz mastositoz, mastositoz

Corresponding Author/Sorumlu Yazar: Deniz Özçeker E-mail: denizozceker@gmail.com

Submitted/Başvuru: 29.03.2021 • Revision Requested/Revizyon Talebi: 09.08.2021 • Last Revision Received/Son Revizyon: 03.09.2021 •

Accepted/Kabul: 03.09.2021 


\section{INTRODUCTION}

Mastocytosis is a disease in which mast cells proliferate and accumulate excessively in organs such as the spleen, liver, skin, lymph nodes, gastrointestinal tract, and bone marrow (1). In children, there are two types of mastocytosis; cutaneous mastocytosis, which is more common and involves only the skin and systemic mastocytosis, which is less common and may involve bone marrow or other organs (2). According to the World Health Organization's new classification in 2016, cutaneous mastocytosis is classified as maculopapular cutaneous mastocytosis/urticaria pigmentosa (UP), solitary mastocytosis (SM), and diffuse skin mastocytosis (3). UP, which is the most common form, mostly progresses in infancy with fixed rashes in the form of red-brown maculopapular plaques, nodules, and bullae on the scalp, face, extremities, and trunk (4). A sudden rash may appear on the lesions as a result of cold water, hot bath, or exercise (5). In the type of solitary mastocytoma containing single or multiple brownish nodules, sudden hypotension and flushing may develop as a result of physical trauma such as friction of the nodules (6) and adrenaline should be used during this hypotensive attack (7).

The goal of this study was to find out about the demographic variables and clinical features of patients with cutaneous mastocytosis, to investigate the levels of knowledge of families, and to raise awareness about the disease, which is not recognized much.

\section{MATERIAL AND METHODS}

Twenty-five pediatric cutaneous mastocytosis patients tracked in the pediatric oncology and pediatric immunology and allergy outpatient clinics between the years 2017 and 2020 were included in the study. Age, gender, age at the first complaint, age at diagnosis, follow-up period, type according to WHO classification, location, bulla formation, Darier's sign, reaction history with procedures such as vaccination, operation, and tooth extraction, family history, resolution of the disease findings, tryptase levels, and biopsy results were recorded from the patient archives. During routine patient controls, a questionnaire was applied to the families to evaluate their knowledge about the disease.

Clinical and histological examinations were used to make the diagnosis for cutaneous mastocytosis, and hemogram, kidney and liver function tests, bone marrow aspiration, and abdominal ultrasonography were performed in suspicious cases to determine whether there was any other organ involvement.

\section{Ethics}

This study was approved by the local Ethical Committee (2020/33). Before taking part in the study, all of the participants signed a written informed consent form.

\section{Statistical analysis}

The results of this study were statistically analyzed using IBM SPSS Statistics 22 software (SPSS IBM, Turkey). While evaluating the data obtained from the study, we used descriptive statistics such as mean, standard deviation, and frequency.

\section{RESULTS}

The male $(n=16 ; \% 64)$ to female $(n=9 ; \% 36)$ ratio was $1: 1.7$. The mean age of onset of the complaint was $14 \pm 24.03$ months (Table 1).

Table 1: Descriptive characteristics of the patients.

\begin{tabular}{|c|c|c|}
\hline & $\mathbf{n}$ & $\%$ \\
\hline Female & 16 & 64,0 \\
\hline \multirow[t]{2}{*}{ Male } & 9 & 36,0 \\
\hline & Mean $\pm S D *$ & $\begin{array}{l}\text { Minimum- } \\
\text { maximum }\end{array}$ \\
\hline Age of onset of complaint (month) & $14,6 \pm 24,03$ & $1-120$ \\
\hline Age of diagnosis (month) & $22,76 \pm 37,01$ & $2-192$ \\
\hline Follow-up period (month) & $39,16 \pm 23,86$ & $6-114$ \\
\hline
\end{tabular}

*SD: Standard deviation

Of the patients, $60 \%(n=15)$ were diagnosed with UP and $40 \%$ $(n=10)$ with solitary mastocytosis. We did not have any patients with diffuse cutaneous mastocytosis.

Lesions were on the trunk in $40 \%(n=10)$ of the patients, trunk and extremity in $20 \%(n=5)$, head, neck and trunk in $16 \%$ $(n=4)$ and head, neck, trunk and extremities in $24 \%(n=6)$. All the patients were vaccinated on time and no reaction was observed. Tooth extraction and/or circumcision surgery was performed on 11 patients, but none of them had an anaphylactic reaction during these procedures. Only 2 of our patients, one during exposure to sudden heat and the other during febrile infection, had an attack accompanied by sudden flushing and hypotension. However, both of the patients did not put the adrenaline auto-injector into action during the attack.

The mean tryptase level was $6.41 \mathrm{mcg} / \mathrm{L}(0-11.4 \mu \mathrm{cg} / \mathrm{L})$ and the tryptase level was not found above the threshold in any of our patients (Table 2).

Table 2: Clinical and laboratory findings of patients.

\begin{tabular}{ll}
\hline Clinical picture & \\
Type & Urticaria pigmentosa (UP) \\
& Solitary mastocytoma (SM) \\
Location & UP: \\
& Common to the whole \\
& body \\
& Extremity and trunk \\
& Trunk and head-neck \\
& SM: \\
& Trunk \\
Head-neck
\end{tabular}

Bulla formation

Itching

Darier's sign

Reaction with vaccination

Tooth exctraction and/or circumcision

Laboratory

Mean \pm standard deviation (SD)

Triptase level (mcg/L)

$6,41 \pm 4,13$ 
In the survey conducted to measure the level of knowledge, $20 \%(n=7)$ of the families described mastocytosis as an allergic disease, $40 \%(n=10)$ as a skin disease, and $20 \%(n=5)$ as a condition affecting both skin and the other internal organs, while $12 \%(n=3)$ of them had no idea about the disease. It was found that $88 \%(n=22)$ of the patients were diagnosed by a dermatologist and $12 \%(n=3)$ by a specialist for allergic diseases.
Only 2 of our patients had adrenaline auto-injectors with them. While $60 \%$ of the families $(n=15)$ had fears about the disease; of these 15 families, $53.3 \%(n=8)$ were afraid of the re-spread of the disease, $13.3 \%(n=2)$ turning of the disease into skin cancer, $13.3 \%(n=2)$ occupation of the internal organs, $13.3 \%$ $(n=2)$ having a new attack, and $0.4 \%(n=1)$ re-forming of the spots (Table 3 ).

Table 3: Level of the knowledge of the families.

\begin{tabular}{|c|c|c|c|}
\hline Question & Answer & $\mathbf{n}$ & $\%$ \\
\hline \multirow[t]{3}{*}{ What kind of disease is mastocytosis? } & Allergic disease & 7 & 28,0 \\
\hline & Skin disese & 10 & 40,0 \\
\hline & A disease involving both skin and internal organs & 5 & 20,0 \\
\hline \multirow[t]{2}{*}{ Medical specialist making the diagnosis } & Dermatologist & 22 & 88 \\
\hline & Specialist for allergic diseases & 3 & 12 \\
\hline \multirow[t]{6}{*}{ Do you know what can be seen during your illness? } & Itching & 14 & 56 \\
\hline & Skin spots & 20 & 80 \\
\hline & Sudden rash on the skin & 3 & 12 \\
\hline & Hypotension & 0 & 0 \\
\hline & Syncope & 0 & 0 \\
\hline & No idea & 1 & 4 \\
\hline \multirow[t]{2}{*}{ Have you ever had a sudden attack? } & No & 23 & 92 \\
\hline & Yes & 2 & 8 \\
\hline \multirow[t]{6}{*}{ What did you experience during the attack? } & Itching & 0 & 0 \\
\hline & Sudden rash on the skin & 2 & 8,0 \\
\hline & Hypotension & 0 & 0 \\
\hline & Syncope & 0 & 0 \\
\hline & Palpitation & 0 & 0 \\
\hline & Other & 0 & 0 \\
\hline \multirow[t]{7}{*}{ What was your attack triggered by? } & Pungent odor & 0 & 0 \\
\hline & Tooth extraction & 0 & 0 \\
\hline & Bug bite & 0 & 0 \\
\hline & Warm & 1 & 4 \\
\hline & Exercise & 0 & 0 \\
\hline & Spicy foods & 0 & 0 \\
\hline & Infection & 1 & 4 \\
\hline \multirow[t]{2}{*}{ Did you use adrenaline during the attack? } & No & 25 & 100 \\
\hline & Yes & 0 & 0 \\
\hline \multirow[t]{2}{*}{ Do you carry an adrenaline auto-injector? } & No & 23 & 92 \\
\hline & Yes & 2 & 8 \\
\hline \multirow[t]{2}{*}{ Do you have fears about your illness? } & No & 10 & 40 \\
\hline & Yes & 15 & 60 \\
\hline \multirow[t]{4}{*}{ What fears do you have about your illness? } & Spread to more areas & 9 & 36 \\
\hline & Skin cancer development & 2 & 8 \\
\hline & Involvement of internal organs & 2 & 8 \\
\hline & Having an anaphylaxis attack & 2 & 8 \\
\hline
\end{tabular}




\section{DISCUSSION}

Mastocytosis, which affects most commonly skin in the pediatric group, is a disorder in which mast cells proliferate excessively and accumulate in one or more organs (7). The frequency of the disease varies between studies. In a study in Mexico, the frequency of the disease was 1:500, while in a study conducted in Turkey, it was determined as 1:234 $(8,9)$. According to most previous studies, the disease affects boys more than girls. The ratio of Male/Female has been identified as 1.7:1 in the Netherlands (10), 1.5:1 in Israel (11), 1.8:1 in Mexico (8), and 1.5:1 in Turkey (12). In a review including 90 studies, the ratio was 1.4:1 (13). In our study, unlike other studies, our rate was found to be $1: 1.7$, with a higher rate of female patients. We think that this difference might be due to the small number of our patients.

Age at the onset of the disease is momentous because of being a prognostic factor (10), and the fact that the disease starts before the age of 5 has been determined to be an indicator of a good prognosis (14). We found that in more than half of our patients (64\%), the disease started before the age of 1 . Similarly, in the study of Kiszewski et al. (8), it was reported that lesions started in the first year in $92 \%$ of the patients, and Akoglu et al. (12) showed that approximately $80 \%$ of the lesions appeared before the first birthday. In a comprehensive study, $90 \%$ of the cases got a diagnosis under the age of 2 and about $4 \%$ of them showed familial transmission (13). Positive family history was present in only one of our patients, but the patient's brother could not be evaluated because he lived in another city.

The frequencies of the types of cutaneous mastocytosis differ between studies. Ben Amitai et al. reported the UP type with a rate of $65 \%$ and the SM type with a rate of $34 \%$ in their study with 180 patients (11). Akoglu et al. found the UP type with a rate of $80 \%$ and the SM type with a rate of $20 \%$ (12). In a study with a large number of patients, the rate of the UP type was $74 \%$ and the rate of the SM type was $19 \%$ (13). In accordance with the literature, the rate of the UP type was $60 \%$ and the rate of the SM type was $40 \%$ in our study. It is possible to say that the UP form of cutaneous mastocytosis is more frequent than the other types seen in childhood.

The distribution of lesions varies among subtypes of cutaneous mastocytosis. Hannaford et al. found that lesions were widely detected in the whole body in patients with UP, while they were more localized in the trunk in patients with SM (15). Tüysüz et al. reported that patients with UP usually had widespread lesions in the whole body, while SM cases had more lesions on the trunk and extremities (16). In our study, the head, neck, and trunk were the only affected parts of the body in just $26 \%$ of the patients with UP. In $90 \%$ of the patients with SM, the lesion was on the trunk, and in $10 \%$ of them, the lesions were on the head and neck. While the lesions have a wider spread in UP cases, they are mostly located on the trunk in SM patients.

According to the previous studies, most of the patients complained of itching. Serarslan et al. (9), in $50 \%$ of the cases, and Kiszewski et al. (8), in $61 \%$ of the cases, detected itching symptoms. Similarly, itching was present in $56 \%$ of our cases. Since mast cell mediators play a role in the pathogenesis, symptoms such as itching and rash are expected (14).

Darier's sign is the urticarial rash occurring with the irritation of the lesion. Although the specificity of the Darier sign is high, it is not completely sensitive (9). Kiszewski et al. (8), in $94 \%$ of the cases, and Akoglu et al. (12), in $89.5 \%$ of the cases with UP, reported a Darier's sign. In a review, Darier's sign was found with a rate of $91 \%$. In our study, in accordance with the literature, the rate of Darier's sign was $88 \%$.

According to the 2016 diagnostic criteria for systemic mastocytosis, a serum tryptase level of $>20 \mathrm{mcg} / \mathrm{L}$ is considered to be significant. Recent studies have shown that high serum tryptase levels may also be associated with larger skin involvement (17). In our study, while the mean serum tryptase level of the patients was $6.41 \pm 4.13$ ( $\mathrm{mcg} / \mathrm{L}$ ), no systemic involvement was detected.

The cutaneous mastocytosis is clinically diagnosed and histopathologically confirmed. In histopathology, the accumulation of mast cells and their metachromatic staining with Giemsa and Toluidin blue dyes are determined (7). In addition, the expression of markers of cell membrane such as CD2, CD68, and CD117 (stem cell growth factor receptor c-kit) helps in the diagnosis (14). In the skin biopsies of our patients, all of them were CD117 positive, and metachromatic staining with Giemsa and Toluidin blue dyes was detected.

Over time, cutaneous mastocytosis can turn into a systemic form or severe hypotensive attacks may be resulted from the sudden discharge of mast cells. Also, excessively hot showers, unexpected temperature fluctuations, physical stimulation, hard scratching of the skin, anxiousness, bee stings, alcohol, aspirin, morphine, codeine, and radiocontrast agents with iodine can all cause anaphylaxis in these patients (7).

When the knowledge levels of the families about mastocytosis and its course were examined, only $20 \%$ of the families knew that mastocytosis could affect both the skin and other organs and $12 \%$ had no idea about the disease. When families were asked about the symptoms, $80 \%$ of them stated spots on the skin, $56 \%$ of them stated itching, and $12 \%$ of them stated sudden rash on the skin. Most of the families believed that mastocytosis was just a skin disease, and for this, they firstly consulted a dermatologist. Thus, $88 \%$ of the patients were diagnosed by a dermatologist, and only $12 \%$ by a specialist of allergic diseases. The families did not sufficiently know this disease, which could have serious consequences, and did not have enough knowledge about the symptoms.

Although it was prescribed to all patients, only two of them were carrying adrenaline auto-injectors. Unfortunately, both patients who had an attack did not use an adrenaline autoinjector. We think that it is necessary to provide patients with continuous training on the necessity of carrying an adrenaline auto-injector and how to use it during an attack. 
Childhood cutaneous mastocytoses generally tend to disappear spontaneously in adolescence (10). In $15-30 \%$ of the cases continuing in adulthood, the disease may turn into the systemic type (18). However, according to our survey results, most of the families were afraid of the spread of the disease and even the development of skin cancer. Only the families of two patients had a fear of developing organ involvement. In patients with mastocytosis, which requires multisystemic follow-up, physicians of dermatology, allergy, hematology, and genetics should provide adequate training to families about the course of the disease. Also, the families should be helped to get rid of unnecessary worries.

The importance of adequately informing families, who have limited knowledge about the disease, about the symptoms and prognosis of the disease and treatment of attacks has become clearer with this questionnaire. Although transformation to a systemic form is rare, families should also be informed about this possibility.

Etik Komite Onayı: Bu çalışma yerel etik kurul tarafindan onaylanmıştır (2020/33).

Bilgilendirilmiş Onam: Kathlımcılardan bilgilendirilmiş onam alınmıştır.

Hakem Değerlendirmesi: Dış bağımsız.

Yazar Katkıları: Çalışma Konsepti/Tasarım- D.Ö.; Veri Toplama- T.A.; Veri Analizi/Yorumlama- T.A.; Yazı Taslağı- T.A.; İçeriğin Eleştirel İncelemesiD.Ö., E.T.; Son Onay ve Sorumluluk- T.A., E.T., D.Ö.

Çıkar Çatışması: Yazarlar çıkar çatışması beyan etmemişlerdir.

Finansal Destek: Yazarlar finansal destek beyan etmemişlerdir.

Ethics Committee Approval: This study was approved by the Local Ethical Committee (2020/33).

Informed Consent: Written consent was obtained from the participants.

Peer Review: Externally peer-reviewed.

Author Contributions: Conception/Design of Study- D.Ö.; Data Acquisition- T.A.; Data Analysis/Interpretation- T.A.; Drafting Manuscript- T.A.; Critical Revision of Manuscript- D.Ö., E.T.; Final Approval and Accountability- T.A., E.T., D.Ö.

Conflict of Interest: Authors declared no conflict of interest.

Financial Disclosure: Authors declared no financial support.

\section{REFERENCES}

1. Valent P, Horny H-P, Escribano L, LongleyB J, LiC Y, SchwartzL B, et al. Diagnostic criteria and classification of mastocytosis: a consensus proposal. Leukemia Research 2001;25:603-25.
2. Hartman K, Metcalfe DD. Pediatric mastocytosis. Hematol Oncol Clin North Am 2000;14:625-40.

3. Valent P, Akin C, Hartmann K, Nilsson G, Reiter A, Hermine O, et al. Advances in the Classification and Treatment of Mastocytosis: Current Status and Outlook toward the Future. Cancer Res 2017; 77(6):1261-70.

4. Ferrante G, Scavone V, Muscia MC, Adrignola M, Corsello G, Passalacqua $G$, et al. The care pathway for children with urticaria, angioedema, mastocytosis. World Allergy Organ J 2015;8:5.

5. Azana JM, Torrelo A, Mediero IG, Zambrano A. Urticaria pigmentosa: a review of 67 pediatric cases. Pediatr Dermatol 1994;11:102-6.

6. Carter MC, Metcalfe DD. Paediatric mastocytosis. Arch Child 2002;86:315-9.

7. Zeynep Tamay, Deniz Özçeker Current approach to cutaneous mastocytosis in childhood Turk Pediatri Ars 2016;51:123-7.

8. KiszewskiAE, Durán-Mckinster C, Covarrubias LO, Castrellón PG, Maldonado RR. Cutaneous mastocytosis in children: a clinical analysis of 71 cases AE 2004 European Academy of Dermatology and Venereology JEADV 2004;18:285-90.

9. Serarslan G, Atik E, Canda Ş. Pediatric Cutaneous Mastocytosis: Demographic, Clinical and Histopathological Findings. Turkish Journal of Dermatology 2008;2:69-72.

10. Middelkamp Hup MA, Heide R, Tank B, Mulder PGH, Oranje AP. Comparison of mastocytosis with onset in children and adults. J Eur Acad Dermatol Venereol 2002;16:115-20.

11. Ben-Amitai D, Metzker A, Cohen HA. Pediatric cutaneous mastocytosis: a review of 180 patients. Isr Med Assoc J 2005;7:3202.

12. G Akoglu, G Erkin, B Cakir, G Boztepe, S Sahin, A Karaduman, et al. Cutaneous mastocytosis: demographic aspects and clinical features of 55 patients. European Academy of Dermatology and Venereology 2006;20:969-73.

13. Meni C, Bruneau J, Georgin-Lavialle S, Peufeilhoux LS, Damaj G, Hadj-Rabia S, et al. Paediatric mastocytosis: a systematic review of 1747 cases. Br J Dermatol 2015;172(3):642-51.

14. Heide R, Tank B, Oranje AP. Mastocytosis in childhood. Pediatr Dermatol 2002;19:375-81.

15. Hannaford R, Rogers M. Presentation of cutaneous mastocytosis in 173 children. Australas J Dermatol 2001;42:15-21.

16. Tüysüz G, Özdemir N, Apak H, Kutlubay Z, Demirkesen C, Celkan T. Childhood mastocytosis: results of a single center Türk Ped Arş 2015;50:108-13.

17. Alvarez-Twose I, Vañó-Galván S, Sánchez-Muñoz L, Morgado JM, Matito A, Torrelo A, et al. Increased serum baseline tryptase levels and extensive skin involvement are predictors for the severity of mast cell activation episodes in children with mastocytosis. Allergy 2012;-67:813-21.

18. Kettlehut B, Metcalfe D. Pediatric mastocytosis. J Invest Dermatol 1991;96:15-8. 